\title{
Long Non-Coding RNA UBA6-ASI Promotes the Malignant Properties of Glioblastoma by Competitively Binding to microRNA-760 and Enhancing Homeobox A2 Expression [Retraction]
}

Cheng F, Liu J, Zhang Y, et al. Cancer Manag Res. 2021;13:379-392.

The Editor and Publisher of Cancer Management and Research wish to retract the published article. Concerns were raised over the western blot and flow cytometry data presented in the article. The authors responded to our initial queries but were unable to provide satisfactory original data for their study. Given concerns relating to the validity of the study's findings the Editor advised for the article to be retracted.

Our decision-making was informed by our policy on publishing ethics and integrity and the COPE guidelines on retraction.

The retracted article will remain online to maintain the scholarly record, but it will be digitally watermarked on each page as "Retracted".

\section{Publish your work in this journal}

Cancer Management and Research is an international, peer-reviewed open access journal focusing on cancer research and the optimal use of preventative and integrated treatment interventions to achieve improved outcomes, enhanced survival and quality of life for the cancer patient.
The manuscript management system is completely online and includes a very quick and fair peer-review system, which is all easy to use. Visit http://www.dovepress.com/testimonials.php to read real quotes from published authors. 